\title{
Keefektifan Model NHT (Numbered Heads Together) Berbantu Media Sapuan Terhadap Hasil Belajar Matematika
}

\author{
Ardian Pahlevi ${ }^{*}$, Aries Tika Damayani ${ }^{2}$, Kiswoyo $^{3}$ \\ 1,2,3Pendidikan Guru Sekolah Dasar, Fakultas Ilmu Pendidikan, Universitas PGRI Semarang
}

\author{
A R T I C LEINFO \\ Article history: \\ Received 18 Desember \\ 2017 \\ Received in revised form \\ 30 Desember 2017 \\ Accepted 15 Januari 2018 \\ Available online 20 \\ Februari 2018 \\ Kata Kunci: \\ Model Numbered Heads \\ Together, Media Sapuan, \\ Hasil Belajar \\ Keywords: \\ Numbered Heads Together \\ Model, Sweeping Media \\ Learning Outcomes.
}

\begin{abstract}
A B S T R A K
Latar belakang yang mendorong penelitian ini adalah rendahnya hasil belajar siswa kelas I SD Negeri Tlogosari Kulon 01. Nilai hasil belajar matematika siswa kelas 1 yang masih banyak siswa tidak memenuhi KKM. Hal ini disebabkan kurangnya penggunakan model dan media pembelajaran yang memperjelas konsep-konsep abstrak dalam pembelajaran Matematika. Penelitian ini bertujuan untuk mengetahui seberapa besar keefektifan model NHT (Numbered Heads Together) berbantu media sapuan terhadap peningkatan hasil belajar siswa ranah kognitif pada mata pelajaran MATEMATIKA kelas 1 SD Negeri Tlogosari Kulon 01. Desan penelitian ini menggunakan desain One-Group Pretest-posttest. Populasi pada penelitain ini adalah seluruh siswa kelas I SD Negeri Tlogosari Kulon 01.. Teknik pengumpulan data pada penelitian ini yaitu wawancara, tes, observasi dan dokumentasi. Hasil Penelitian ini dapat disimpulkan bahwa model pembelajaran NHT (Numbered Heads Together) berbantu media sapuan terhadap hasil belajar Matematika siswa kelas 1 efektif. Hal ini dapat dilihat dari hasil rata-rata nilai posttest siswa meningkat $20,18 \%$ dari hasil nilai pretest. Selain itu diperkuat dengan hasil peritungan uji-t diperoleh sebesar 21,36193 dan sebesar 2,048, karena $(21,36193)>(2,048)$ maka hal itu menunjukan bahwa uji t signifikan.
\end{abstract}

\section{A B S T R A C T}

The background that drivers this research is the low learning outcomes of class 1 students of class 1 SDN Tlogosari Kulon 01. The value of mathematics learning outcomes of grade 1 students who are still many students do not met the KKM. This is due to the luck of use of models and instructional media that clarify abstract concepts in MTHEMATICS learning. The problem of this search is how the effectives models NHT (Numbered Heads Together) Sweeping media assistance to improve cognitive learning outcomes of students in the MATHEMATICS class 1 SDN Tlogosari Kulon 01. The purpose of the research is to know how big the effectiveness of models NHT (Numbered Heads Together) Sweeping media assistance toward increasing cognitive domain learning outcomes in Mathematics subjects grade I SD Negeri Tlogosari Kulon 01. The design of this study uses the design of One Group Postets-prettest. The population in this study were all students in class I SD Negeri Tlogosari Kulon 01. The researcher took a sample of the population of class I Studentds at SD Negeri Tlogosari Kulon 01, totalling 28 students. Data collections techniques in this study are interviews, tests, observation, and documentations. The results of this study can be concluded that the media-assisted learning model strokes the MATHEATICS larning outcomes of class 1 students effectively. This can be seen from the average value of students Posttest values increased by $20,18 \%$ from the results of Pretest. Besides that, is reinforced by the results of the t-test obtained by of 21,36193 and of 2,048 , because $(21,36193)>$ then it shows that the t-test is significant 


\section{Pendahuluan}

Pendidikan merupakan upaya manusia untuk memperluas pengetahuan dalam rangka untuk membentuk nilai, sikap, dan perilaku. Pendidikan juga merupakan salah satu sarana untuk mengembangkan potensi diri dan keterampilan siswa melalui proses pembelajaran sebagai bekal bagi dirinya menjalani hidup bermasyarakat, berbangsa dan bernegara. Sebagaimana dalam Undang-Undang No. 20 Tahun 2003 tentang Sistem Pendidikan Nasional pasal 1 ayat 1 dalam Sudharto (2009:3) secara tegas menyatakan bahwa :

"Pendidikan merupakan usaha sadar dan terencana untuk mewujudkan suasana belajar dan proses pembelajaran agar siswa secara aktif mengembangkan potensi dirinya untuk memiliki kekuatan spiritual keagamaan, pengendalian diri, kepribadian, kecerdasan, akhlak mulia, serta keterampilan yang diperlukan dirinya, masyarakat bangsa dan nengara".

Sedangkan dalam buku Dictionary of Education di dalam buku karangan Sudharto (2009:4) pendidikan adalah proses sosial di mana orang dihadapkan pada pengaruh lingkungan yang terpilih dan terkontrol (khususnya yang datang dari sekolah), sehingga dia dapat memperoleh atau mengalami perkembangan kemampuan sosial dan kemampuan individu secara optimal. Dalam hal ini sekolah sebagai tempat penyelenggara sangat sentral terutama keberadaan peran dan fungsi guru merupakan salah satu faktor yang sentral bagi siswa karena guru sebagai fasilitator untuk perekmbangan siswa itu sendiri. Guru merupakan bagian terpenting dalam proses belajar mengajar, di jalur pendidikan formal, informal, atau nonformal. Guru dalam mengajar juga tidak terlepas dari model pembelajaran dan media pembelajaran.

Menurut Joice \& Weil 1980 dalam buku Sari, Eka Setianingsih (2016:118) mendefinisikan model pembelajaran sebagai kerangka konseptual yang digunakan sebagai pedoman dalam melakukan pembelajaran. Model pembelajaran dapat membantu guru dalam kegiatan belajar mengajar siswa. Pada kenyataannya pembelajaran masih kurang maksimal karena guru kurang memanfaatkan model dan media pembelajaran secara maksimal. Sering sesekali guru menggunakan metode konvensial sehinggga hasil belajar siswa kurang maksimal. Penerapan model NHT (Numbered Heads Together) diharapkan dapat membantu Susana belajar yang efektif dan membuat siswa aktif, sehingga hasil belajar siswa pada mata pelajaran matematika meningkat. Dalam pelaksanaan pembelajaran peneliti juga menggunakan model sapuan yang diharapkan dapat membantu siswa dalam memahami materi yang disampaikan oleh guru dan diharapkan juga dapat meningkatkan hasil belajar siswa.

Pembelajaran NHT (Numbered Heads Together) merupakan salah satu tipe pembelajaran kooperatif yang menekankan pada struktur-struktur khusus dirancang untuk mempengaruhi pola-pola interaksi siswa dan memiliki tujuan untuk meningkatkan penguasaan tingkat akademik (La Iru dan La Ode Safiun Arihi, 2012:59). Kemudian model tersebut di bantu dengan media Satuan dan Puluhan (Sapuan) yang di harapkan dapat meningkatkan hasil belajar siswa.

Guru merupakan pihak yang berhubungan langsung dengan siswa, sehingga dalam memberikan evaluasi diharapkan lebih akurat,objektif dan mengoptimalkan pembelajaran. Hakim (2009:50) mengemukakan "siswa diharapkan dapat membangun pemahamannya sendiri tentang realita alam dan ilmu pengetahuan dengan cara merekonstruksi sendiri melalaui pemahaman pribadinya". Hasil belajar digunakan sebagai tolak ukur yang digunakan untuk menentukan keberhasilan pendidikan formal. Hasil pembelajaran diperoleh setelah melaksanakan kegiatan pembelajaran.

Berdasarkan hasil wawancara di SD Negeri Tlogosari Kulon 01 pada tanggal 4 Oktober 2018. Menurut guru kelas 1 ibu Mursidah,peneliti mendapatkan informasi bahwa siswa kelas 1 begitu kurang memahami mata pelajaran matematika, dalam penerapan pembelajaran guru menggunakan metode ceramah di selingi tanya jawab. Namun metode tersebut masih kurang maksimal sehinggal hasil belajar siswa kurang maksimal. Hal tersebut bisa dilihat dari data hasil belajar nilai matematika kelas 1 Tahun pelajaran 2018.

Tabel 1. Daftar Nilai UTS Siswa

\begin{tabular}{lllll}
\hline No & Aspek & Nilai & Siswa & Keterangan \\
\hline 1 & Nilai Tuntas & $70-100$ & - & LULUS \\
2 & NIlai Remidi & $1-69$ & - & REMIDI \\
3 & Rata-rata & 74,5 & - & KELAS I \\
4 & KKM & 70 & - & - \\
5 & Siswa Lulus & $>70$ & 15 & LULUS \\
6 & Siswa Remidi & $<70$ & 4 & REMIDI \\
7 & Siswa Lulus & 70 & 9 & LULUS \\
\hline \multicolumn{2}{r}{} & \multicolumn{2}{r}{ Sumber: Daftar Nilai Siswa Kelas I SDN Tlogosari Kulon 01 }
\end{tabular}


Maka dapat dilihat pada Tabel 1, masih banyak siswa yang tidak tuntas dalam hasil belajar pada mata pelajaran matematika kelas 1 SD Negeri Tlogosari Kulon 01 maka perlu diadakan perbaikan terhadap hasil belajar mata pelajaran matematika. Berdasarkan permasalahan di atas guru harus mampu merancang media pembelajaran yang mampu membuat siswa lebih aktif dan dapat memabntu siswa untuk memahami suatu konsep yang di sampaikan oleh guru sesuai tujuan pembelajaran yang diharapkan.

Media pembelajaran memiliki peranan yang sangat besar untuk meningkatkan hasil belajar siswa. Media pembelajaran bukan sekedar berfungsing sebagai alat bantu mengajar, melaikan media itu sendiri juga dapat memerankan fungsi sebagai penyampai pesan belajar. Dengan begitu, tidak semua informasi pelajaran harus disampaikan oleh guru. Untuk itu setiap kali menjalankan perannya sebagai pengajar, guru membutuhkan bantuan media.

Media adalah segala sesuatu yang dapat digunakan untuk menyalurkan pesan dari pengirim ke penerima sehinga dapat merangsang pikiran, perasaan, perhatian, dan minat serta perhatian sedemikian rupa sehingga proses belajar terjadi Sadirman Sari, Eka Setianingsih (2016:173) . Sedangkan menurut Kemp (199:43), pembelajaran yang menggunakan media yang tepat akan memberikan hasil yang optimal bagi pemahaman siswa terhadap materi yang sedang dipelajarinya. Penggunaan media Sapuan diharapkan dapat membantu siswa untuk termotifasi lebih aktif dalam mengikuti proses belajar mengajar dan diharapkan dapat meningkatkan hasil belajar mengajar pada mata pelajaran matematika. Berdasarkan latar belakang di atas peneliti tertarik untuk meneliti tentang keefektifan model NHT (Numbered Heads Togheter) berbantu media Sapuan terhadap hasil belajar matematika kelas 1 SD Negeri Tlogosari Kulon 01 semester genap tahun pelajaran 2018/2019.

Berdasarkan latar belakang di atas berikut hasil identifikasi masalah yang ada adalah sebagai berikut: 1) Model pembelajarn yang di gunakan oleh guru yaitu model pembelajaran ceramah dan Tanya jawab masih kurang maksimal dalam proses kegiatan belajar mengajar, 2) Guru kurang memanfaatkan media pembelajaran dalam kegiatan belajar mengajar, 3) Guru belum menggunakan media sapuan, 4) Guru belum menggunakan media NHT (Numbered Heads Together).

Dari identifiksi masalah di atas maka peneliti membatasi masalah pada keefektifan model NHT (Numbered Heads Togheter) berbantu media sapuan terhadap hasil belajar ranah kognitif pada mata pelajaran matematika kelas 1 SD Negeri Tlogosari Kulon 01. Berdasarkan latar belakang, identifikasi masalah dan pembatasan masalah maka diambil rumusan masalah yaitu keefektifan model NHT (Numbered Heads Together) berbantu media sapuan terhadap hasil belajar ranah kognitif pada mata pelajaran matematika kelas 1 SD Negeri Tlogosari Kulon 01.

Berdasrkan rumusan masalah, diperoleh tujuan penelitian ini adalah untuk mengetahui keefektifan model NHT (Numbered Heads Together) berbantu media sapuan terhadap hasil belajar ranah kognitif pada mata pelajaran matematika kelas 1 SD Negeri Tlogosari Kulon 01 tahun pelajaran 2018/2019.

\section{Metode}

Dalam penelitian ini menggunakan metode eksperimen dengan tujuan untuk melihat dari suatu perlakuan. Pada eksperimen ini perlakuan atau kelas yang mendapat perlakuan dengan merapkan model pembelajaran NHT (Numbered Heads Together) berbantu media Sapuan dalam penelitian ini adalah siswa kelas I SD Negeri Tlogosari Kulon 01. Penelitian ini menggunakan desain One-Group Pretestposttest. Design pada pada desain ini terdapat pretest, sebelum diberi perlakuan. Dengan demikian hasil perlakuan dapat diketahui lebih akurat, karena dapat membandingkan dengan keadaan sebelum diberi perlakuan.

Desain ini dapat digambarkan sebagai berikut.$$
\mathrm{O}_{1} \mathrm{X} \mathrm{O}_{2}
$$

Keterangan:

$O_{1}=$ Nilai Pretest (sebelum diberi perlakuan)

$\mathrm{O}_{2}=$ Nilai posttest (setelah diberi perlakuan)

Pengaruh perlakuan terhadap hasil belajar siswa $=O_{2}-O_{1}$

Teknik Pengumulan data pada penelitian ini adalah wawancara, tes, obsrvasi dan dokumentasi. Wawancara bertujuan untuk mndapatkan informasil awal karakteristik pada siswa serta materi yang akan diajarkan. Tekhnik tes yang digunakan dalam penelitian ini adalah unutuk menilai kemampuan siswa 
yang mencangkup pengetahuan hasil belajar siswa. Soal tes berbentuk pilihan ganda dengan jumlah soal 40 dan soal akan di uji coba ke SD Negeri Tlogosari Kulon 01 dan akan dihitung kevalidan sebelum digunakan untuk penelitian. Setelah diukur kevalidannya soal yang semula 40 kemudian dihitung kevaliditasannya menjadi 20 soal dan digunakan untuk penelitian.

Dokumentasi dalam penelitian ini adalah untuk mencari data berupa nama siswa, jumlah siswa, dan data lainnya yang diperlukan selama melakukan penelitian. Metode dokumentasi ini juga digunakan untuk memperoleh nilai siswa, aftar nama siswa dan data-data lainnya. Selain wawancara dalam penelitian ini juga menggunakan tekhnik observasi yang mana peneliti melihat kondisi real di lapangan dalam kegiatan blajar mengajar. Hal ini bertujuan untuk mengetahui situasi kondisi siswa yang akan di jadikan sebagai sampel dalam penelitian

\section{Hasil dan Pembahasan}

Penelitian ini menerapkan model NHT (Numbered Heads Together) pada media sapuan kelas I SD Negeri Tlogosari Kulon 01.

Tabel 2. Daftar Hasil Penelitian Siswa Kelas kelas I SD Negeri Tlogosari Kulon 01

\begin{tabular}{lll}
\hline Keterangan & Pretest & Posttest \\
\hline Jumlah Siswa & 28 & 28 \\
Siswa yang tuntas & 11 & 24 \\
Siswa yang tidak tuntas & 17 & 4 \\
Jumlah nilai & 1675 & 2240 \\
Rata-rata nilai & 59,82 & 80,00 \\
\hline
\end{tabular}

Sumber: Analisis Hasil Penelitian

Berdasarkan hasil post-test menggunakan tes kemampuan belajar matematika, diperoleh hasil bahwa rata-rata nilai hasil belajar matematika siswa pada materi penempatan puluhan dan satuan adalah 80 dengan siswa yang tuntas sebanyak 24 siswa dan siswa yang tidak tuntas sebanyak 4 siswa. Sedangkan rata-rata nilai pretest hasil belajar matematika siswa materi penempatan puluhan dan satuan adalah 59,82 dengan siswa yang tuntas sebanyak 11 dan siswa yang tidak tuntas sebanyak 17 siswa. Jadi perbedaan rata-rata hasil pretest dan hasil posttest siswa pada kelas kontrol dan kelas eksperimen yaitu dengan selisih 20,18.

Dari hasil yang diperoleh dapat disimpulkan bahwa rata-rata nilai posttest setelah menggunakan model pembelajaran NHT (Numbered Heads Together) berbantu media sapuan lebih tinggi dibandingkan dengan rata-rata nilai pretest sebelum menggunakan model pembelajaran NHT (Numbered Heads Together). Hal ini dapat dilihat pada gambar diagram dibawah ini.

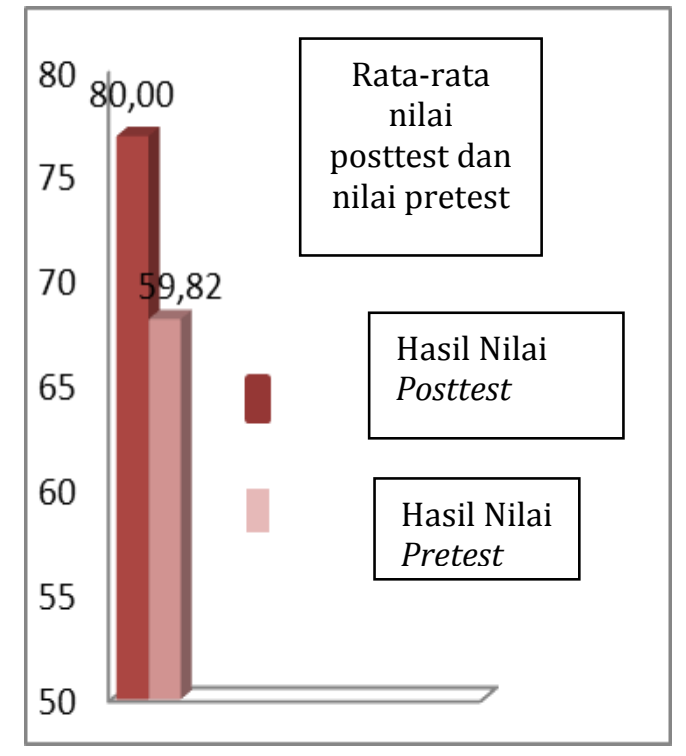

Gambar 1. Diagram Data 
Hasil Penelitian Jadi, berdasarkan data hasil post-test dan pretest, dapat disimpulkan bahwa ada perbedaan hasil belajar matematika antara setelah menggunakan model pembelajaran NHT (Numbered Heads Together) berbantu media sapuan dengan sebelum menggunakan model pembelajaran NHT (Numbered Heads Together).

Uji normalitas awal dalam penelitian ini digunakan sebagai data awal yaitu nilai pretest.

Tabel 3. Uji Normalitas Awal Hasil Pretest

\begin{tabular}{ll}
\hline Keterangan & Pretest \\
\hline Lo & 0.1305 \\
Ltabel & 0.161 \\
\hline
\end{tabular}

Berdasarkan Tabel 3 di atas dengan taraf nyata 5\% pada hasil Pretest $\mathrm{L}_{\mathrm{o}}(0,1305)<\mathrm{L}_{\text {tabel }}(0,161)$ maka $\mathrm{H}_{0}$ diterima sehingga sampel berasal dari populasi berdistribusi normal. Uji normalitas akhir dalam penelitian ini digunakan sebagai data akhir nilai post-test.

Tabel 4. Uji Normalitas Akhir Hasil Postest

\begin{tabular}{ll}
\hline Keterangan & Pretest \\
\hline Lo & 0.1587 \\
Ltabel & 0.161 \\
\hline
\end{tabular}

Berdasarkan Tabel 4 di atas dengan taraf nyata $5 \%$ pada hasil Post-test $\mathrm{L}_{0}(0,1587)<\mathrm{L}_{\text {tabel }}(0,161)$ maka $\mathrm{H}_{0}$ diterima sehingga sampel berasal dari populasi berdistribusi normal.

Analisis data akhir digunakan untuk menguji hipotesis dengan menggunakan uji t. Data yang digunakan yaitu nilai pretest yaitu nilai siswa sebelum diberikan pembelajaran menggunakan model NHT (Numbered Heads Together) dan nilai posttest yaitu nilai siswa setelah diberi NHT (Numbered Heads Together) berbantu media sapuan.

Data yang diperoleh dari hasil belajar sebelum mendapat perlakuan dan setelah mendapat perlakuan dapat dihitung menggunakan uji t. Dimana hasil perhitungan rata-rata sebelum menggunakan model NHT (Numbered Heads Together) sebesar 59,82 sedangkan rata-rata setelah menggunakan model NHT (Numbered Heads Together) berbantu media sapuan sebesar 80,00.

Ho :bahwa model Numbered Heads Together lebih efektif terhadap kemampuan bercerita pada siswa kelas I SD Negeri Tlogosari Kulon 01.

Ha :bahwa model Numbered Heads Together efektif terhadap kemampuan bercerita pada siswa kelas I SD Negeri Tlogosari Kulon 01.

Adapun hasil perhitungan dapat dilihat tabel berikut:

Tabel 5. Rekapitulasi Uji t

\begin{tabular}{cc}
\hline Data & Hasil \\
\hline thitung & 21,36913 \\
t table & 2,048 \\
\hline
\end{tabular}

Berdasarkan Tabel .5 di atas diperoleh taraf nyata 5\% dengan diperoleh data hasil belajar dengan $t_{\text {hitung }}(21,26913)>t_{\text {tabel }}(2,048)$ maka $H_{a}$ diterima, artinya bahwa model Numbered Heads Together efektif terhadap kemampuan bercerita pada siswa kelas I SD Negeri Tlogosari Kulon 01.

Ketuntasan belajar individual dinyatakan sudah tercapai apabila peserta didik telah menguasai sekurang-kurangnya 70\% terhadap materi setiap bahasan yang diajukan. Ketuntasan belajar klasikal 85\% dari jumlah peserta didik secara keseluruhan mencapai KKM. Berikut tabel ketuntasan belajar peserta didik: 
Tabel 6. Tingkat Ketuntasan hasil Belajar

\begin{tabular}{ccccc}
\hline NO & Hasil Belajar & $\begin{array}{c}\text { Tingkat Ketuntasan } \\
\text { Minimal }\end{array}$ & Tuntas & Presentase \\
& & $85 \%$ & $1139,29 \%$ & $1760,71 \%$ \\
\hline 1 & Pretest & $85 \%$ & $2485,71 \%$ & $414,29 \%$ \\
\hline
\end{tabular}

Sumber : Data Hasil Penelitian (2018)

Persentase ketuntasan belajar peserta didik menunjukkan bahwa pembelajaran tanpa model pembelajaran NHT (Numbered Heads Together) berbantu media Sapuan sebanyak 11 peserta didik yang tuntas dengan persentase $39,29 \%$ dan 17 peserta didik yang belum tuntas dengan persentase 60,71. Kemudian setelah diberi perlakuan dengan menggunakan model pembelajaran NHT (Numbered Heads Together) berbantu media Sapuan, ada 24 peserta didik yang tuntas dengan persentase $85,71 \%$ dan 4 peserta didik yang belum tuntas dengan persentase $14,29 \%$.

\section{Simpulan dan Saran}

Berdasarkan hasil penelitian dan pembahasan, maka dapat disimpulkan bahwa model (NHT) Numbered Heads Togheter berbantu media sapuan efektif terhadap hasil belajar ranah kognitif pada mata pelajaran matematika kelas 1 SD Negeri Tlogosari Kulon 01. Dapat dilihat dari hasil penelitian diketahui bahwa nilai hasil posttest adalah 80,00 dan nilai hasil pretest adalah 59,82 Sedangkan hasil analisis uji T dengan thitung= 21,36193 dan ttabel= 2,048 maka thitung $>$ ttabel sehingga HO ditolak dan Ha diterima, artinya model (NHT) Numbered Heads Togheter berbantu media sapuan efektif terhadap hasil belajar ranah kognitif pada mata pelajaran matematika kelas 1 SD Negeri Tlogosari Kulon 01.

Dari hasil simpulan yang telah dipaparkan di atas, maka perlu adanya beberapa saran, yaitu: 1 . Hendaknya para guru lebih kreatif dan bervariasi dalam menggunakan model dan metode pembelajaran sesuai dengan materi yang akan disampaikan serta kondisi lingkungan sekitar sekolah. 2. Guru hendaknya mencoba menggunakan model pembelajaran model (NHT) Numbered Heads Togheter berbantu media sapuan karena model ini melibatkan siswa untuk aktif secara keseluruhan untuk menciptakan suasana pembelajaran yang menyenangkan dan bermakna. 3. Siswa sebaiknya lebih semangat dalam belajar untuk memperoleh ilmu, pengetahuan, meningkatkan kemampuan berpikir dan kemampuan memecahkan masalah dengan cara mengikuti pembelajaran dengan baik dan sungguh-sungguh.

\section{Daftar Rujukan}

Alvario, Prilusma. 2016. Efektivitas Media Papan Flanel Dalam Meningkatkan Kemampuan Perkalian Pada Anak Tunarungu Kelas IV di SDN No 35 (SDLB) Painan Utara. E-JUPEKku. Volume 5 Nomor 1.

Anitah, Sri W.Dkk. 2012. Strategi Pembelajaran di SD, Edisi 1. Tanggerang Selatan: Universitas Terbuka.

Arikunto, Suharsimi. 2012. Dasar-dasar Evaluasi Pendidikan, Edisi 2. Jakarta: PT Bumi Ksara.

Arikunto, Suharsimi. 2010. Manajemen Penelitian. Jakarta.: PT Rineka Cipta

Arikunto, Suharsimi. 2010. Prosedur Penelitian Suatu Pendekatan Praktik. Jakarta: PT Rineka Cipta

Baharudiin, Esa Nur Wahyuni.2015. Teori Belajar \& Pembelajaran. Yogyakarta: Ar-Ruzz Media.

Fathani, Abdul Salim. 2018. Matematika Hakikat \& Logika. Jogjakarta: Ar-Ruzz Media.

Gede, I Budi Astrawan. 2014. Penerapan Model Kooperatif Tipe NHT Dalam Meningkatkan Hasil Belajar Mata Pelajaran IPA Kela V SDN 3 Tonggolobibi. .https//scholar.google.co.id. Jurnal.untad.ac.id. Jurnal Kreatif Tadulako Online 3 (4), 2014

Hamdaya, Jumanta. 2016. Metodologi Pengajaran. Jakarta: PT Bumi Aksara.

Karso, dkk. 2012. Pendidikan Matematika 1, Edisi 1. Tanggerang Selatan: Universitas Terbuka. 
Kusumawati, Hanifah dan Mawardi. 2016. Perbedaan Penerapan Model Pembelajaran Kooperatif Tipe NHT dan STAD Ditinjau dari Hasil Belajar Siswa. https//scholar.google.co.id. Scholaria : Jurnal Pendidikan dan Kebudayaan 6 (3), 251-263, 2016.

Muhsetyo, Gatot, Dkk. 2016. Pembelajaran Matematika sd, Edisi 1. Tanggerang Selatan: Universitas Terbuka.

Noviyanti, Ervin. 2018. Keefektifan Media Sapuan (satuan danpuluhan) Pada Model Pembelajaran Cooperative Tipe Think Pair Share (TPS) Terhadap Hasil Belajar Matematika Kelas I SDN 01 Mororejo. Skripsi. FIP, Pendidikan Guru Sekolah Dasar. Universitas PGRI Semarang.

Rafika, Fela Erza.2016. Pengaruh Dari Penerapan Model NHT Terhadap Hasil Belajar Matematika Berbantu Media Konkret Siswa Kelas IV SDN Maribaya 01 Kab.Tegal. Buku Elektronik. File PDF. 8 Oktober 2018.

Republik Indonesia. 2003. Undang-Undang No. 20 Tahun 2003 Tentang System Pendidikan Nasional Bab 1 Pasal 1. Sekertariat Negara. Jakarta.

Sadirman, dkk. 2011. Media Pendidikan: Pengertian, Pengembangan dan Pemanfaatannya. Jakarta: PT Rajawali Pers.

Setianingsih, Ekasari, Rahmat Rais dan Asep Ardiyanto. 2016. Strategi Belajar Mengajar. Semarang: Universitas PGRI Semarang.

Sudjana, Nana. 2014. Penilaian Proses Belajar Mengajar. Bandung: PT Remaja Rosdakarya.

Sudjana, Nana. 2005. Metode Statistika. Bandung: PT Tarsito Bandung.

Sugiyono. 2017. Metode Penelitian Pendidikan Pendekatan Kuantitatif Kualitatif dan R \& D. Bandung: Alfabeta.

Sukardi.2011. Metodologi Penelitian Pendidikan Kompetensi dan Prakteknya. Jakarta: PT Bumi Aksara.

Sundayana, Restina. 2013. Media dan Alat Peraga Dalam Pembelajaran Matematika. Garut: Alfabeta.

Susanto, Ahmad.2013. Teori Belajar Pembelajaran di Sekolah Dasar. Jakarta: Prenadamedia Group.

Taufik, Agus, Hera L Mikarsa, Puji L Prianto. 2013 Pendidikan Anak di SD, Edisi 1. Tanggerang Selatan.. 